\title{
EFL LEARNERS' PHONOLOGICAL INTERFERENCE OF ENGLISH ARTICULATION
}

\author{
Ambalegin ${ }^{1}$ \\ Universitas Putera Batam, Batam, Indonesia \\ abhi140475@gmail.com \\ Fasaaro Hulu ${ }^{2}$ \\ Universitas Putera Batam, Batam, Indonesia \\ fashulu@gmail.com
}

\begin{abstract}
This research investigated the mispronunciation of Putera Batam University EFL learners by adapting the standard of Received Pronunciation (RP) and the factors of English vowels and consonants mispronunciation. This descriptive qualitative research applied observational method with participatory technique in collecting data, and articulatory identity method in analyzing the data. The English mispronunciation was found in the EFL learners' English pronunciation. The consonant sounds $/ \mathrm{d} /, / \theta /, / \mathrm{t}^{\mathrm{h}} /, / \mathrm{z} /, / \mathrm{r} /, / \mathrm{g} /, / \mathrm{g} /, / \mathrm{d} \mathrm{z} /, / \mathrm{nj} /$, and consonant-closed syllable sound of $/ \mathrm{k} /$ were pronounced incorrectly. The consonant sound $/ \mathrm{d} /$ was pronounced as $/ \mathrm{d} /, / \theta / \mathrm{as} / \mathrm{t} /, / \mathrm{t}^{\mathrm{h}} /$ as $/ \mathrm{t} /, / \mathrm{z} / \mathrm{as}$ $\mid \mathrm{j} /, / \mathrm{r} /$ as $/ \mathrm{r} /, / \mathrm{g} /$ as $/ \mathrm{s} /, / \mathrm{t} / \mathrm{h} / \mathrm{s} /, / \mathrm{d} /$ as $/ \mathrm{d} /$, and $/ \mathrm{nj} /$ is pronounced as $/ \mathrm{n} /$. Consonant-closed syllable sound of $/ \mathrm{k} /$ is articulated as / $/$ /. The vowel sounds /ə/ and /æ/ were pronounced incorrectly as /e/ and the diphthong sound /eI/ were pronounced incorrectly as /e/. These mispronunciation phenomena were caused by some factors based on their background. The factors were; the mother tongue interference (native language), the differences between Indonesian and English sound systems (phonetic ability), the educational background, and the environmental background (amount of exposure).
\end{abstract}

Keywords: consonants, mispronunciation, Received Pronunciation (RP), vowels

\section{INTRODUCTION}

English is taught as a foreign language in schools with Standard English. Standard English is generally used in the news, media, and in literary works. Standard English is sometimes used as a cover term for all standard varieties of English such as spelling, vocabulary, grammar, and particularly pronunciation. Learning pronunciation possess the Received Pronunciation (RP). RP becomes more and more widely spoken accents in formal schools. But nowadays American English (AE) exposes to a lot of TV programs, in films, in literature more than British English (BE). Nevertheless AE and $\mathrm{BE}$ are not too separated languages. Each area of English speaking has developed its own special characteristics, e.g. vocabulary and pronunciation.
Speaking foreign language has been sighted as the most demanding of the four skills. For the most people, speaking ability is related to knowing the language since speaking is the most fundamental principle of the human communication (Celce-Murcia, 2001). What makes speaking second or foreign language difficult? Many of SL or FL speakers were shocked when they used their SL or FL for the first time in the real interaction. Brown (2007) stated that speaking is seen as the central skill, the he agreed that speaking is the integration of many subsystems to make speaking a second or foreign language and becomes formidable task for language learners yet for many people. In oral way all elements must be involved, according to Harris (as cited in 
Ambalegin, Suhardianto, \& Kaprawi, 2017), pronunciation, grammar, vocabulary, fluency, and comprehension are the basic important elements of speaking.

Hinofotis and Baily (as cited in Ambalegin \& Arianto, 2018) said that neither vocabulary nor grammar makes ESL/EFL learners faulty but pronunciation is in communication process. EFL students must concern pronunciation as one of the top priorities (Davis as cited in Ambalegin \& Arianto, 2019). Fraser (as cited in Gilakjani, 2016) mentioned that English-spoken ability includes vocabulary, grammar, and pragmatic, etc. of which pronunciation is far from the most important, and she argued that with a good pronunciation, a speaker is intelligibly drives away from the errors; poor pronunciation, English difficult understanding, despite accuracy in other areas.

Teaching pronunciation is fundamentally important for the EFL learners. Teaching pronunciation is focused on the segmental features and stress and intonation. However, many teaching materials still do not make clear that pronunciation is just one tiny piece of the whole course credits. Seidlhofer (as cited in Murcia, 2001) clearly said that pronunciation never ends itself but a means of negotiating meaning in discourse, embedded in sociocultural and interpersonal contexts. Pronunciation instruction needs to be taught as communicative interaction along with other aspects of spoken discourse such as pragmatic meaning and nonverbal communication.

Allen (as cited in Hakim, 2012) stated that pronunciation has a big contribution for better English speaking. Learning pronunciation is not as simple as a process of memorizing a number of items that can be mapped on to mother tongue. Indonesia has a lot of mother tongues that also interfere other languages' pronunciation. By the use of mother tongue or native language as a home language will form the speaker's speech organ system as well as the native-accent and mother tongue-accent (Ambalegin \& Suryani, 2018).

EFL students who learned English faced difficulties in speaking English. Pronunciation is the important skill in speaking English (Gilakjani as cited in Lin, 2014). Pronunciation brings a meaningful instruction in teaching English as FL. Problem in pronouncing weakens the communicative competence. However, many of university students lack sufficient proficiency in pronouncing even if English is taught since elementary level. Needless to say, teaching correct pronunciation emphasizes to acknowledge errors in pronunciation and correct them in order to improve the ability of students' pronunciation.

Having had experience in teaching pronunciation to EFL first semester learners at Putera Batam University, whose students are able to speak Indonesian from some ethnicities such as Batak Toba-nese and Karonese (North Sumatera), Javanese (Java), Minangnese (West Sumatera), Malay (Kepulauan Riau), Oki (Palembang), Kemak and Marae (East Nusa Tenggara), Buginese and Makassarese (South Sulawesi), and Chinese experience difficulty in pronouncing English sounds such as the combination of $\langle$ th>, the end sound of $\langle\mathrm{ch}\rangle$, and the end sound $/ \mathrm{k} /$. Experiencing the English pronunciation difficulties made by the EFL learners, it investigated the incorrect English pronunciation and the factors of incorrect English pronunciation made by the EFL students.

\section{LITERATURE REVIEW}

2.1 Vowels, Diphthongs, Triphthongs, and Consonants

1. Vowels 
Low (2015) described that vowels are the sound production of with no obstruction in the vocal tract. According to Kelly (2004), there are three categories of vowel sounds based on the characteristics of the articulation; closed vowel sounds (/i:/ /I/ / / / /u:/), mid vowel sounds (/e//ə//3://o:/), and open vowel sounds $(/ æ / / \Lambda / / \mathrm{a}: / / \mathrm{p} /)$.

a. Vowel Length

Vowel length is important in English pronunciation to distinct feature in the language. this as /ðis/ and these as /ði:s/ experience different meaning due to the different vowel sound length. Colon [;] marks the long vowels (McMahon, 2002).

b. Reduced Vowel

There are some letters pronounced silently (Okeke, 2008). build is pronounced as /bild/ that there is no $\langle\mathrm{u}\rangle$ pronounced. Vowels are able to be omitted in some contexts because some extended following syllabic consonant $/ \mathrm{r} /, / \mathrm{l} /, / \mathrm{n} /$ in the syllable absorb the vowel sound such as recruit as /rikrot/, bottle as /bptl/, and minute as /minit/.

\section{c. Nasalization}

Nasalized vowels are indicated by a tilde $(\sim)$ marked above the vowels [ê] [û]. Vowels are able to be nasalized when air passes through the nasal cavity.

\section{Diphthongs}

There are three categories of diphthong sounds based on the characteristics of the articulation; centering diphthongs (/Iə/ /ひə/ /eə/), closing diphthong ending in // / (/eI/ /oI/ /aI/), and closing diphthong ending in / $/ /$

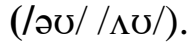

Finegan (2015) stated that diphthong is produced when the tongue starts producing vowel in one place and glides to another. Kelly (as cited in Ambalegin \& Arianto, 2018) agreed that diphthong is the combination of two vowels. He cleared that the tongue glides from one vowel articulation to another vowel position to produced diphthongs.

3. Triphthongs
Roach (2012) stated that triphthongs have the most complicated vowel sounds as they are difficult to be articulated, and recognized. A triphthong is a collaboration of three vowel sounds where tongue rapidly and uninterruptedly moves away from first vowel articulation to another vowel articulation, then to a third vowel. Roach (2012) listed the triphthongs with five close diphthongs with schwa /ə/ еөә (as in mayor, crayon), arə (as in choir, buyer), эю (as in loyal, royal), ә0ә (as in lower, mower), and aбə (as in flower, coward).

\section{Consonants}

A consonant is produced by a partial or complete close of vocal tract (Finegan, 2015). Speech sound is able to be characterized based on the articulatory properties. The consonants are articulated in three characteristics: voicing, place of articulation, and manner of articulation (Low, 2015). Completely, Low (2015) and Yule (2014) described three term labels describing the main characteristic.

a. Voicing

It can be heard by differentiating between [t] and [d]. When $/ \mathrm{d} /$ and $/ \mathrm{t} /$ are pronounced, the position of tongue within the mouth is the same, but these sounds are different from the vibration in the larynx when pronounces $/ \mathrm{d} /$ that it is called voicing (Low, 2015).

b. Place of Articulation

Place of articulation produced different sounds due to the airflow in the lips, oral and nasal cavity, pharynx, and glottis (Low, 2015). According to Yule (as cited in Al-Zayed, 2017), the seven kinds place of articulation; bilabials, labiodentals, dentals, alveolar, palatal, velar, and glottal are seen below.

1. Bilabials

The sound is articulated with upper and lower lips such as symbol [p] put (voiceless /p/), symbol [b] but (voiced $/ \mathrm{b} /$ ), and symbol [m] may (voiced $/ \mathrm{m} /$ ). 
Symbol [w] is bilabial in way, walk, world.

\section{Labiodentals}

The sound is articulated with upper teeth and the lower lip such as symbol [f] fat, symbols [p] photo (voiceless /f/), and symbol [v] vat (voiced /v/) and safe, cough and save (the final sounds /f/ and /v/).

3. Dentals

The position of tongue tip behind upper front teeth pronounces dental sound. Think and teeth are voiceless dentals symbolized by theta $/ \theta /$. The, there, then, feather are voiced dental symbolized by /ð/ ("eth").

4. Alveolars

Front tongue on the alveolar ridge produces alveolars such as tip, deep, say, zoo and not. /t/ and /s/ are voiceless whereas $/ \mathrm{z} /, / \mathrm{n} /$, and $/ \mathrm{d} /$ are voiced. $/ \mathrm{l} /$ in like and light and $/ \mathrm{r} /$ in right and run are other alveolars.

5. Palatals

A hard part in the mouth roof is behind the alveolar ridge. Front tongue and hard palate produces palatals or alveopalatals. shy and catch are voiceless palatals. $s h$ is symbolized as [J] and $c h$ is symbolized as [t]]. Measure is voiced palatals symbolized as [3]. Badge is also voiced palatals symbolized as [d] . [j] is the other voiced palatal such as yes and young.

6. Velars

Beyond the hard palate, soft palate or velum is at the mouth roof. Back of the tongue against the velum produces velars. A voiceless velar is symbolized as [k] such as kind, come, and queen. A voiced velar is heard in good, game, and ghost symbolized as [g]. sing is represented by [y]. [y] is nasal voiced velar because the air flows through nasal cavity.

7. Glottals

Glottal is pronounced with no tongue and other parts of the mouth actively. $/ \mathrm{h} /$ occurs in home, hey, whose, who. [h] is voiceless glottal. Glottis is between vocal folds in larynx. When the glottis opens and the air passes out of the mouth freely, $/ \mathrm{h} /$ is produced.

c. Manner of Articulation

Manner of articulation is how consonants pronounced. Yule (as cited in Maiza, 2014) mentioned that manner of articulation in consonants consist of stops, affricative, nasal, liquid, fricative and glides which stated below.

1. Stops

Stop or plosive is articulated by blocking or stopping effect of the air stream. Phonemes [b, d, g, k, p, t] are produced by stopping of the air stream and letting it go unexpectedly.

2. Affricative

The combination of stops and fricatives (friction) produces voiceless affricates / $\mathfrak{g} /$ and voiced affricates $/ \mathrm{d} z /$.

3. Nasal

The position of velum is lowered touching the tongue back and the air streams, finally the air flows out through the nose to produce voiced nasals $/ \mathrm{m} /, / \mathrm{n} /$ and $/ \mathrm{y} /$.

4. Liquid

The air flows around the sides of the tongue as the tongue tip touches the alveolar ridge. It pronounces voiced liquids in /r/ and lateral voiced liquid /1/.

5. Fricative

/f, $v, \theta, \delta, s, z, \int, z /$ are pronounced when the air stream is almost blocked and air is pushed through the very narrow opening. Fricatives occur when there is a friction as the air is pushed through.

6. Glides

The voiced glides are $/ \mathrm{w} /$ and $/ \mathrm{j} /$. They are also semi-vowels because they can act as 
vowel /i/ and / $/ /$. Tongue glides to or from the vowels' position when glide is pronounced.

\subsection{Factors Affecting Pronunciation}

Carter \& Nunan (2001) said that mother tongue clearly influences on learning L2 pronunciation, while mother tongue-like accent is interfering the English pronunciation, phonology performs one's knowledge of the sound system of a language, then it concerns with a competence.

Kenworthy (1987, pp. 4-7) stated that factors that affect pronunciation are shown as follows.

a. The Native Language

The more different the native language sounds characteristics from English, the more difficult someone pronounces English.

b. The Age Factor

This is a contrastive analysis. Some researchers concluded that age influences the accuracy of a learner's pronunciation; others argued that age does not interference in pronouncing foreign sounds.

c. Amount of Exposure

It is showing to view this simply as a matter of whether the speaker lives in an English-speaking country or not. If this is the case, then the speaker is 'surrounded' by English and this constant exposure should affect pronunciation skills.

d. Phonetic Ability

This skill has been variously termed 'aptitude for oral mimicry', 'phonetic coding ability' or 'auditory discrimination ability'. Researchers have designed tests which measure this ability and have demonstrated that some people are able to discriminate between two sounds better than others, and/or are able to mimic sounds more accurate.

e. Attitude and Identity
It was claimed that factors such as a person's 'sense of identity' and feelings of 'group affiliation' are strong determiners of the acquisition of accurate pronunciation of a foreign language.

\section{RESEARCH METHOD}

This qualitative-descriptive research (Creswell, 2012) used the competence in observation method and participatory technique (Sudaryanto, 2015) in collecting data. The data were taken by interviewing, noting, and recording. The data were analyzed by identification the EFL learners' pronunciation. The sounds produced by the EFL learners were explained related to articulatory properties and place of articulation in the vocal tract for the consonants and the anatomy of the vowels. Then, the sounds were analyzed to match based on Oxford dictionary (RP). Finally, the sounds pronounced incorrectly were identified to find out the mispronunciation of phonetic articulation. The English sound mispronunciation was the final result for the EFL learners English pronunciation difficulties. This analysis applied identity method in term of articulatory phonetic identity (Sudaryanto, 2015). The EFL learners' background taken from the deep interview was the information to draw the factor influencing the English pronunciation difficulties.

\section{RESULT AND DISCUSSION}

There were 41 first semester EFL learners taking the pronunciation class. There were 11 ethnics which brought their own characteristics. But 9 students have stayed in Batam as the residents. Their home-language did not influence their pronunciation. While pronouncing the English sounds, the EFL Learners made some mistakes. Below are the tables the sound pronounced incorrectly by the EFL learners.

4.1 The English Mispronunciation

Table 1. The Number of Students' English Mispronunciation 


\begin{tabular}{|c|c|c|c|c|c|}
\hline \multirow[b]{2}{*}{ No } & \multirow{2}{*}{$\begin{array}{c}\text { Soun } \\
\text { ds }\end{array}$} & \multicolumn{2}{|c|}{ Before Practicing } & \multicolumn{2}{|c|}{ After Practicing } \\
\hline & & Number & $\begin{array}{l}\text { Percent } \\
\text { age }(\%)\end{array}$ & Number & $\begin{array}{c}\text { Percenta } \\
\text { ge }(\%)\end{array}$ \\
\hline 1 & /ð/ & 38 & $93 \%$ & 35 & $93 \%$ \\
\hline 2 & $/ \theta /$ & 34 & $83 \%$ & 31 & $76 \%$ \\
\hline 3 & $/ \mathrm{t} /$ & 35 & $85 \%$ & 30 & $85 \%$ \\
\hline 4 & /z/ & 25 & $61 \%$ & 20 & $49 \%$ \\
\hline 5 & $/ \mathrm{r} /$ & 31 & $76 \%$ & 25 & $61 \%$ \\
\hline 6 & $/ \mathrm{d} /$ & 30 & $73 \%$ & 29 & $71 \%$ \\
\hline 7 & $/ \mathrm{t} \int /$ & 27 & $68 \%$ & 24 & $59 \%$ \\
\hline 8 & /dz/ & 23 & $56 \%$ & 22 & $54 \%$ \\
\hline 9 & $/ \mathrm{nj} /$ & 40 & $98 \%$ & 35 & $85 \%$ \\
\hline $\begin{array}{l}1 \\
0\end{array}$ & $/ \mathrm{k} /$ & 25 & $61 \%$ & 22 & $54 \%$ \\
\hline $\begin{array}{l}1 \\
1\end{array}$ & /a/ & 38 & $93 \%$ & 22 & $54 \%$ \\
\hline $\begin{array}{l}1 \\
2\end{array}$ & /3:/ & 35 & $85 \%$ & 5 & $12 \%$ \\
\hline $\begin{array}{l}1 \\
3\end{array}$ & /æ/ & 40 & $98 \%$ & 38 & $93 \%$ \\
\hline $\begin{array}{l}1 \\
4\end{array}$ & /eI/ & 38 & $93 \%$ & 31 & $76 \%$ \\
\hline $\begin{array}{l}1 \\
5\end{array}$ & /Іә/ & 22 & $54 \%$ & 7 & $17 \%$ \\
\hline
\end{tabular}

Table 2. The EFL Learners' English Mispronunciation

\begin{tabular}{|c|c|c|c|c|c|}
\hline No & Words & Standard RP & $\begin{array}{l}\text { EFL Learners' } \\
\text { Pronunciation }\end{array}$ & $\begin{array}{l}\text { Correct } \\
\text { Sounds }\end{array}$ & $\begin{array}{l}\text { Mispr } \\
\text { onun- } \\
\text { ciation }\end{array}$ \\
\hline 1 & the, & /ðе/ & $/ \mathrm{de} /$ & $/$ /ठ/ & $/ \mathrm{d} /$ \\
\hline 2 & this & /ðIs/ & /dIs/ & /ð/ & $/ \mathrm{d} /$ \\
\hline 3 & think, & $/ \theta \mathrm{Ink} /$ & $/ \mathrm{tIn} /$ & $/ \theta /$ & $/ \mathrm{t} /$ \\
\hline 4 & thank & 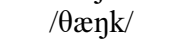 & /ten/ & $/ \theta /$ & $/ \mathrm{t} /$ \\
\hline 5 & ten & $/ \mathrm{t}^{\mathrm{h}} \mathrm{en} /$ & $/$ ten/ & $/ \mathrm{t}^{\mathrm{h}} /$ & $/ \mathrm{t} /$ \\
\hline 6 & two & $/ t^{\mathrm{h}} \mathrm{u}: /$ & $/ \mathrm{tu} /$ & $/ \mathrm{t}^{\mathrm{h}} /$ & $/ \mathrm{t} /$ \\
\hline 7 & thousand & 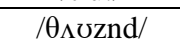 & /tıujen/ & /z/ & $/ \mathfrak{j} /$ \\
\hline 8 & busy & /bIzI/ & /bIsI/ & $|z|$ & $/ \mathrm{s} /$ \\
\hline 9 & easy & /i:zI/ & /i:jI/ & $|z|$ & $\mid \mathfrak{j} /$ \\
\hline 10 & reading, & $/$ rIdIg/ & /ridin/ & $/ \mathrm{r} /$ & $/ \mathrm{d} /$ \\
\hline 11 & bar & /ba:(r)/ & $/ \mathrm{b} \Lambda \mathrm{r} /$ & $/ \mathrm{r} /$ & $\mid \mathrm{f} /$ \\
\hline 12 & harbour & /ha:bə(r)/ & /hurbar/ & $/ \mathrm{r} /$ & $/ \mathrm{s} /$ \\
\hline 13 & English, & /InglIJ/ & /InglIs/ & $/ \int /$ & $/ \mathrm{s} /$ \\
\hline 14 & she & $/ \int \mathrm{I} /$ & /sI/ & is/ & $/ \mathrm{s} /$ \\
\hline 15 & such, & $/ \mathrm{s} \wedge \mathrm{t} /$ & /sus/ & $\mid \mathrm{g} /$ & $/ \mathrm{s} /$ \\
\hline 16 & badge & /bædz/ & /bed/ & $/ \mathrm{d} /$ & $/ \mathrm{d} /$ \\
\hline $\begin{array}{l}17 \\
18\end{array}$ & $\begin{array}{c}\text { continue, } \\
\text { annual }\end{array}$ & $\begin{array}{l}\text { /kəntInju:/ } \\
\text { /ænjuəl/ }\end{array}$ & 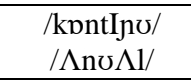 & $\begin{array}{l}\mathrm{nj} / \\
/ \mathrm{nj} /\end{array}$ & $\begin{array}{l}/ \mathrm{n} / \\
/ \mathrm{n} /\end{array}$ \\
\hline $\begin{array}{l}19 \\
20\end{array}$ & $\begin{array}{l}\text { practice, } \\
\text { pragmat } \\
\text { ic }\end{array}$ & $\begin{array}{l}\text { /præktIs/ } \\
\text { /prægmæt } \\
\text { Ik/ }\end{array}$ & $\begin{array}{c}\text { /pre?tIs/ } \\
\text { /pr } \Lambda \mathrm{Pm} \Lambda \mathrm{tik} \\
/\end{array}$ & $\begin{array}{l}/ \mathrm{k} / \\
/ \mathrm{g} /\end{array}$ & $\begin{array}{l}/ \mathrm{P} / \\
/ \mathrm{P} /\end{array}$ \\
\hline 21 & Student & $\begin{array}{c}\text { /stju:d(o)n } \\
t /\end{array}$ & /studen/ & $/ \partial /$ & /e/ \\
\hline 22 & second & /sekənd/ & /seken/ & $/ \partial /$ & /e/ \\
\hline 23 & take & /telk/ & /tek/ & /eI/ & /e/ \\
\hline
\end{tabular}

\begin{tabular}{cccccc}
\hline 24 & cake & $/ \mathrm{keIk} /$ & $/ \mathrm{kek} /$ & $/ \mathrm{eI} /$ & $/ \mathrm{e} /$ \\
25 & make & $/ \mathrm{meIk} /$ & $/ \mathrm{mek} /$ & $/ \mathrm{eI} /$ & $/ \mathrm{e} /$ \\
\hline 26 & bay & $/ \mathrm{beI} /$ & $/ \mathrm{b} \Lambda \mathrm{j} /$ & $/ \mathrm{eI} /$ & $/ \Lambda \mathrm{j} /$ \\
\hline
\end{tabular}

4.2 Discussion

a. Dentals [ $\theta]$ and [ð]

$/ ð /=/ \mathrm{d} /$

$/ \theta /=/ \mathrm{t} /$

$/ \theta /$ and $/ \delta /$ are produced when the tip tongue touches the upper teeth and the air is blocked firstly before it is pushed away. Voiceless $/ \theta /$ and voiced /ð/ are produced from the letter $<$ th> such as think, thank, thing for $/ \theta /$ and the, mother, they for $/ ð /$. Indonesian does not have $/ \theta /$ and $/ ð /$. Mostly the EFL learners pronounced $/ \theta /$ and $/ ð /$ as $/ \mathrm{t} /$ and $/ \mathrm{d} / / \mathrm{t} /$ and $/ \mathrm{d} /$ is voiced and voiceless unaspiratedalveolar that is produced in Indonesian.

b. Alveolars [th], [z], [r]

$/ \mathrm{t}^{\mathrm{h}} /=/ \mathrm{t} /$

English $\langle\mathrm{t}\rangle$ is voiceless fricative (aspirated) stop $/ \mathrm{t}^{\mathrm{h}} /$ (Odden, 2005). EFL learners pronounced $\langle\mathrm{t}\rangle$ as voiceless unaspirated stop $/ \mathrm{t} /$. Indonesian does not have $/ \mathrm{t}^{\mathrm{h}} /$ sound. Aspirated $\left[\mathrm{t}^{\mathrm{h}}\right]$ is pronounced with the friction of air on the tongue. English $/ \mathrm{t}^{\mathrm{h}} /$ is produced when tongue tip touched alveolar placed behind the canine then the air is released as well as the sound $/ \mathrm{t} /$ and $/ \mathrm{h} /$ are produced aspiratedly.

$/ \mathrm{z} /=/ \mathfrak{j} /$

[z] is an alveolar sound in which the position of front tongue touches the protuberance and there is an air friction to produce the fricative sound. For the EFL learners, there is rare to find the /z/ sound in their everyday conversation. $/ j /$ is produced to represent the $/ \mathrm{z} /$ sound such as in izin $=/ \mathrm{IzIn} /$ as $/ \mathbf{j} \mathbf{j} \mathrm{n} /$, zaman $=/ \mathbf{z} \Lambda \mathrm{m} \Lambda \mathrm{n} /$ as $/ \mathfrak{j} \Lambda \mathrm{m} \Lambda \mathrm{n} /$.

$/ \mathrm{r} /=/ \mathrm{r} /$

English and Indonesia's voiced liquid sounds are different in pronouncing. The position of the tongue is hanging in the area of mouth. The tongue does not touch any part of articulatory organs in oral cavity. While the 
$/ \mathrm{r} /$ is produced, the air flow trills the tongue. Then English /r/ is sounded.

The front tongue touches the protuberance while pronouncing the Indonesian / $/$. The air flow is blocked by the tongue, then the air flows through the left and right sides of the tongue. The $/ r /$ is produced while the air flaps the tongue. The vibrating sound is clearly heard.

The EFL learners pronounced / $/$ when pronouncing $/ \mathrm{r} /$. It is caused that there is a different position of tongue between native and EFL learners while pronouncing the voiced liquid sound.

c. Palatal [J], [t]], [d]] [nj]

$/ \mathrm{S} /=/ \mathrm{s} /$

$/ S /$ is a fricative sound that does not exist in EFL learners' language sound. / $/$ / is similar to $/ \mathrm{s} / . / \mathrm{J} /$ is the combination of $\langle\mathrm{s}\rangle$ and $\langle\mathrm{h}\rangle$. The post-alveolar sound $/ \mathrm{J} /$ does not exist in Indonesian. $/ \int /$ is produced when the air flows through the tiny hole made by the tongue. The fricative sound occurs when there is the air friction.

$/ \mathrm{t} f /=/ \mathrm{s} /$

Voiceless palato-alveolar affricate $/ \mathrm{t} f /$ is the combination of $[\mathrm{t}]$ and $[\mathrm{f}]$. [ $\mathrm{t}]$ is voiceless stop and $\left[\int\right]$ is fricative. The combination of voiceless stop and fricative produces voiceless affricative sound. The EFL learners pronounce $[\mathrm{t}]$ ] as $/ \mathrm{s} /$ when $\left[\mathrm{t} \int\right]$ is positioned in the final of consonant-closed syllable sound such as in such /s $\Lambda \mathrm{t} f /$ as $/ \mathrm{s} \Lambda \mathrm{s} /$.

$/ \mathrm{d} /=/ \mathrm{d} /$

Voiced post-alveolar affricate /dz/ is the combination of [d] and [3]. [d] is voiced stop and [3] is fricative. The combination of voiced stop and fricative produces voiced affricative.

EFL learners language has stop [t] and [d] and fricative $[\mathrm{c}],[\mathrm{s}]$, and plosive $[\mathrm{j}]$ but no affricative. The EFL learners pronounced [d] as /d/ when it is positioned in the final consonant-closed syllable sound.
The production sounds of $/ \mathrm{t} J /$ and $/ \mathrm{d} z /$ is started from the tip of the tongue touching the alveolar to produce the sound $/ \mathrm{t} /$ or $/ \mathrm{d} /$ then the plosive is created to produce $/ \mathrm{c} /$ and $/ 3 /$ as well as the air friction over the tongue.

$/ \mathrm{nj} /=/ \mathrm{n} /$

English has no [n]. English separates [n] and [j] while pronouncing such as in /kəntınju:/. EFL learners pronounced continue as /kpntino/.

$/ \mathrm{n} /$ is palatal sound. When the tongue back touches the hard palate, the air flow is blocked by the tongue and flows not through the mouth but the nose. EFL learners could not pronounce the sound [n] and [j] in one differently separated sound production. EFL learners pronounced [n] and [j] as $/ \mathrm{n} /$. . $\mathrm{n}]$ is one single sound produced when the front tongue and palate block the air flow from the lungs then makes the air flow out through the nasal cavity.

d. Consonant-closed syllable sound of velar

$[\mathrm{k}]$ and $[\mathrm{g}]$

practice $=/$ præktıs $/=/$ prePtis $/$

pragmatic $=/$ prægmætık $/=\operatorname{p} \wedge$ $\wedge m \wedge t \mathrm{k}$

$/ \mathrm{k} /=/ \mathrm{P} /$

$/ \mathrm{g} /=/ \mathrm{P} /$

[P] is familiar in EFL learners' language. The consonant-closed syllable sound of $[\mathrm{k}, \mathrm{g}]$ is pronounced as $/ \mathrm{P} /$ in EFL learners' language. The sound / $/$ / influences the EFL learners when pronounce sound $/ \mathrm{k}, \mathrm{g} / \mathrm{in}$ the consonant-closed syllable sound of $[\mathrm{k}, \mathrm{g}]$ of English words. [?] does not produce the sound that functions to stop the previous sound and appears in the final of the consonant-closed syllable sound. When the air from the lungs flows to the pharynx, the air flow is blocked in the glottal a while to end the sound. [?] substitutes the sound velar plosive.

e. Closed-mid central [ə] student $=/$ stju:d(o)nt $/=/$ stoden $/$

second $=/$ sekənd $/=/$ seken $/$

$/ \mathrm{a} /=/ \mathrm{e} /$ 
The EFL learners pronounce a lax vowel /a/ as a tense vowel /e/. It is caused some of the EFL learners brought their mother tongue accent into English such as Batak Toba-nese and Buginese.

f. Mid-open front unrounded [æ]

cat $=/ \mathrm{kæt} /=/ \mathrm{ket} /$

hat $=/$ hæt $/=/$ het $/$

There is no [æ] in EFL learners' language. The sound /a/ is closed to sound /e/ that it belongs to EFL learners' language. [æ] and [e] have the same front position of tongue because the tongue moves forward.

g. Closing-diphthong ending with /i/ [eI]

take $=/$ terk $/=/$ tek $/$

cake $=/$ keIk $/=/$ kek $/$

bay $=/$ bei $/=/$ b $\Lambda \mathbf{I} /$

[eI] is the combination of [e] and [I] that produces diphthong /eI/. In EFL learners' language, there is no diphthong sound /ei/ between consonants. The EFL learners pronounced /eI/ as /e/.

\subsection{Factors Affecting Mispronunciation}

Factors influencing the English vowels and consonants mispronunciation were started from the information of EFL learners' background related to the education background, work experience, and language acquisition. They were born and grew up in Indonesia, in some places where Indonesian and mother tongues are their languages. The EFL learners spent their study in Indonesia. They attended public and private primary schools and high schools. Then, the educators as the ones to transfer the knowledge to the EFL learners gave the courses as well as the textbooks given that (Kieffer \& Lesaux, 2012). The ELF learners informed that English was not a subject to be concerned. As English is not targeted as a habit, makes the EFL learners get problem in learning English (Nagy, Berninger, \& Abbott, 2008) They attended at Putera Batam University majoring of English literature where they did not used to speak English fully. They sometimes used vernaculars to communicate with others and their families.

Vernacular accented-stress influences EFL learners while they were speaking Indonesian or foreign language. Subandowo (2017, pp. 205-206) stated that there are factors influencing while sounding English vowels and consonants such as, mother tongue, the concept of interference, mother tongue interference, concept of pronunciation, English language learning, and speaking ability.

It was found that EFL learners were not able to pronounce the sounds $/ \theta /, / \delta /, / \mathrm{t} /$, $/ \mathrm{z} /, / \mathrm{r} /, / \int, / \mathrm{t} /, / \mathrm{d} z /, / \mathrm{nj} / / \mathrm{o} /, / \mathfrak{a} /$, and /ei/ consonant-closed syllable sound of $/ \mathrm{k} /$. They experienced the mispronunciation of English consonants and vowels because of some factors. The factors are as follows;

a. Mother tongue interference (native language)

Besides Indonesian, the EFL learners used the mother tongue when they communicated at home or with their same ethnic friends. Thus, it influenced their pronunciation when they spoke second or third language.

b. Sound system differences of Indonesian and English (phonetic ability)

Indonesian has 24 consonants and 6 vowels meanwhile English has 24 consonants and 12 vowels, 8 diphthongs, and 5 triphthongs. The speech organs of Indonesians are not prepared to articulate such unfamiliar of English sound systems.

c. Educational background

The EFL learners spent mostly their study in Indonesia. They studied mostly in public primary school in their hometowns where English was not learned. They spent their high schools also in their hometown in public junior and senior high schools. They learnt English in high schools once in a week for two hours. Thus, English was not learnt primarily. 
d. Environmental background (amount of exposure)

The EFL learners have lived in their hometown for more than 15 years. Indonesian and vernaculars were used to communicating among them. It made them have vernacular accented stress. Besides, their environment did not support the use of foreign language or English. It definitely influenced them to pronounce foreign languages or English.

\section{CONCLUSION AND SUGGESTION}

The English mispronunciation was found in the EFL learners' English pronunciation. The consonant sounds $/ ð /, / \theta /$, $/ \mathrm{t}^{\mathrm{h}} /, / \mathrm{z} /, / \mathrm{r} /, / \mathrm{J} /, / \mathrm{g} /, / \mathrm{d} /, / \mathrm{nj} /$, and consonantclosed syllable sound of $/ \mathrm{k} /$ were pronounced incorrectly. The vowel sounds /ə/ and /æ/, and the diphthong sounds /eI/ was pronounced incorrectly. These mispronunciation phenomena were caused by some factors based on their background. The factors influencing the English vowels and consonants mispronunciation of the EFL learners were mother tongue interference (native language), sound systems of Indonesian and English differences (phonetic ability), educational background, and environmental background (amount of exposure).

Considering the positive effect of knowing English as one of the skills to enhance the young generation's future, the basic important elements of English spoken must be taught professionally to upgrade the stage of English into an advanced level especially in teaching English articulation. It was recommended teachers or lecturers to take an in-depth look at the EFL learners' difficulties and problems in pronouncing English. The knowledge of teachers or lectures in English pronunciation becomes a great impact on EFL learners' pronunciation improvement.

\section{REFERENCES}

Al-Zayed, N. N. (2017). Non-native pronunciation of English: problems and solutions. American International Journal of Contemporary Research, 7(3), 86-90. Retrieved from www.aijcrnet.com

Ambalegin, \& Arianto, T. (2018). English vowels and consonants mispronunciation of the seventh president of Republic of Indonesia in his official English speeches and its influencing factors. Langauge Literacy, Journal of Linguistics, Literature, and Language Teaching, 2(2), 113-128. https://doi.org/http://dx.doi.org/10.3074 3/11.v2i2.678

Ambalegin, \& Arianto, T. (2019). A phonology-based study: English pronunciation inconsistency. In The $2 n d$ Annual International Conference on Language and Literature (AICLL 2019) (pp. 106-124). Medan: KnE Social Sciences.

https://doi.org/https://doi.org/10.18502/k ss.v3i19.4834

Ambalegin, Suhardianto, \& Kaprawi, N. (2017). Obstacles facing learners in speaking English: Non-English teachers' perspective, Putra Batam School. Pertanika Journal Social Sciences \& Humanities, 25(1), 122.

Ambalegin, \& Suryani, M. S. (2018). Mother tongue affecting the English vowel pronounciation of Batak Toba adults. In AICLL The 1st Annual International Conference on Language and Literature (pp. 66, 80). Medan: KnE Social Sciences \& Humanities. https://doi.org/10.18502/kss.v3i4.1920

Brown, H. D. (2007). Teaching by principles: An interactive approach to langauge pedagogy (3rd ed.). San Francisco, USA: Pearson Longman.

Carter, R., \& Nunan, D. (2001). The Cambridge to teaching English to 
speakers of other languages (1st ed.). New York: Cambridge University Press. Celce-Murcia, M. (2001). Teaching English as a second or foreign language (3rd ed.). United State of America: Thomson Learning.

Creswell, J. W. (2012). Educational research; planning, conducting, and evaluating quantitative qualitative research (4th ed.). Boston: Pearson Education Inc.

Finegan, E. (2015). Language; Its structure and use (7th ed.). Stamford: Cengage Learning.

Gilakjani, A. P. (2016). English pronunciation instruction: A literature review. International Journal of Research in English Education, 1(1), 2. Retrieved from www.ijreeonline.com

Hakim, M. A. R. (2012). An analysis of phonetics b , d , g, j, ds and ठ into English pronunciation for Java students ( A study on Java students at English Department on STAIN Bengkulu academic year 2011-2012). International Journal of Humanities and Social Science, 2(20), 244, 256. Retrieved from www.ijhssnet.com

Kelly, G. (2004). How to teach pronunciation. England: Pearson Education Limited. Retrieved from www.longman.com

Kenworthy, J. (1987). Teaching English pronunciation. New York: Longman.

Kieffer, M., \& Lesaux, N. (2012). Effects of Academic Language Instruction on Relation and Syntactic Aspects of Morphological Awareness for Sixth Grades from Linguistically Diverse Background. The Elementary School Journal, 112(3), 45-57.

Lin, L.-C. (2014). Understanding pronunciation variations facing ESL students. International Journal of Humanities and Social Science, 4(5), 16-20. https://doi.org/10.30845/ijhss
Low, E. L. (2015). Pronunciation for English as an international language (1st ed.). New York: Routledge Publishers.

Maiza, N. E. (2014). Pronunciation and comprehension of oral English in the English as a foreign language class: Key aspects, students' perceptions and proposals. Journal of Language Teaching and Research, 5(2), 262-273. https://doi.org/104304/jltr 52262-273

McMahon, A. (2002). An introduction to English phonology. Edinburgh: Edinburgh Universiy Press. Retrieved from https://doi.org/10.1159/000328775

Nagy, W. ., Berninger, V. ., \& Abbott, R. . (2008). Contributions of Morphology Beyond Phonology to Literacy Outcomes of Upper Elementary and Middle-School Students. Journal of Educational Psychology, 98(4), 134147.

Odden, D. (2005). Introducing phonology. New York: Cambridge University Press.

Okeke, N. U. (2008). Spelling and phonetic inconsistencies in English: A problem for learners of English as a foreign/second language. African Research Review, 2(1), 64-83.

Roach, P. (2012). English phonetics and phonology; A practical course (4th ed.). Cambridge, UK: Cambridge University Press.

Subandowo, D. (2017). The language interference in English speaking ability for Efl learners. International Seminar on English Language and Teaching, 205-206. Retrieved from ejournal.unp.ac.id/index.php/selt/article/ view/8005

Sudaryanto. (2015). Metode dan aneka teknik analisis bahasa. Yogyakarta: Duta Wacana University Press.

Yule, G. (2014). The study of language (5th ed.). New York: Cambridge University Press. 
